\title{
DIRECT RADIOCARBON DATING OF POTTERY: SELECTIVE HEAT TREATMENT TO RETRIEVE SMOKE-DERIVED CARBON
}

\author{
EMMANUELLE DELQUÉ KOLIČ \\ Centre de Datation par le Radiocarbone, Université Claude Bernard-Lyon I \\ 43, Boulevard du 11 Novembre 1918, F-69622 Villeurbanne Cedex, France
}

\begin{abstract}
I attempted to separate smoke-derived carbon from carbon derived from clay by variable-temperature burning. First, using liquid scintillation counting (LSC) and accelerator mass spectrometry (AMS), I dated experimental potsherds containing these two sources of carbon. I used the same techniques to date archaeological samples. The results on archaeological sherds confirm the difficulty of establishing a standard procedure for pottery dating. Nevertheless, reliable dates on smoke-blackened potsherds are potentially obtainable with AMS dating of thin lamellas in the sherd surface following adequate $\mathrm{NaOH}$ treatment.
\end{abstract}

\section{INTRODUCTION}

The different sources of carbon in potsherds and their influence on ${ }^{14} \mathrm{C}$ dates are now well known (De Atley 1980; Gabasio et al. 1986; Johnson et al. 1986; Hedges, Chen and Housley 1992). The problem that remains is to select carbon related to the period when the potsherd was manufactured and used. It is difficult to separate carbon from organic temper sometimes added by the potter, or from soot produced during firing and food remaining from cooking or storage from older carbon from raw clay and younger carbon introduced by the soil in which the pot is buried. Chemical treatment can eliminate humics, but they cannot differentiate among similar forms of carbon such as soot, pyrolysis temper and pyrolysis organic matter.

My initial interest was in differentiating between carbon added by environmental smoke and carbon from raw clay. Soot is always present on the surface of smoked potsherds, but has no chemical links with the ceramic paste. I used low-temperature combustion, proposed by Evin, Gabasio and Lefevre (1989) to separate organic temper from clay-derived carbon, on potsherds free of this temper but blackened by soot from firing. This method, first used with a sherd dated by liquid scintillation counting (LSC), was adjusted for accelerator mass spectrometry (AMS) dating. I first experimented with potsherds made and fired in the laboratory and followed with archaeological samples. The results, although satisfactory for experimental pots, are sometimes doubtful for archaeological ones. Nevertheless, AMS, thanks to the small quantities required, may provide new ways to directly date blackened pottery.

\section{METHODS}

\section{Experimental Potsherds}

The aim of these experiments was to produce potsherds in which carbon from clay and carbon from smoke were both present. The raw clay was a kaolinite rich in "old" organic matter but free of calcium carbonate. No temper was added. The pots were molded and, after several days of drying, were fired under smoking conditions to obtain the black surface present in sherds from different periods from around the world. If conditions are properly maintained, the kiln shown in Figure 1 produces a suitable reducing atmosphere. During the first few hours, the temperature must be raised slowly (Fig. 2) so that the water is removed from the clay with no damage to the pots. When the temperature reaches $950-1000^{\circ} \mathrm{C}$ at the top of the kiln, the chimney is closed and the maximum temperature maintained for $c a .1 \mathrm{~h}$. The entrance of the fireplace is then hermetically sealed and the dome of the kiln is covered with sand to reduce heat loss. Temperature decreases slowly, and a smoky atmo- 
sphere is produced by the pyrolysis of wood; soot and other complex molecules of carbon and hydrogen form a deposit on the surface and in the superficial porosity of the pots. After $c a .30 \mathrm{~h}$, the kiln is opened.

The potsherds differ in surface aspects: some are black with a metallic sheen, others are dark to light gray. All of them show a more-or-less important gray to black core.

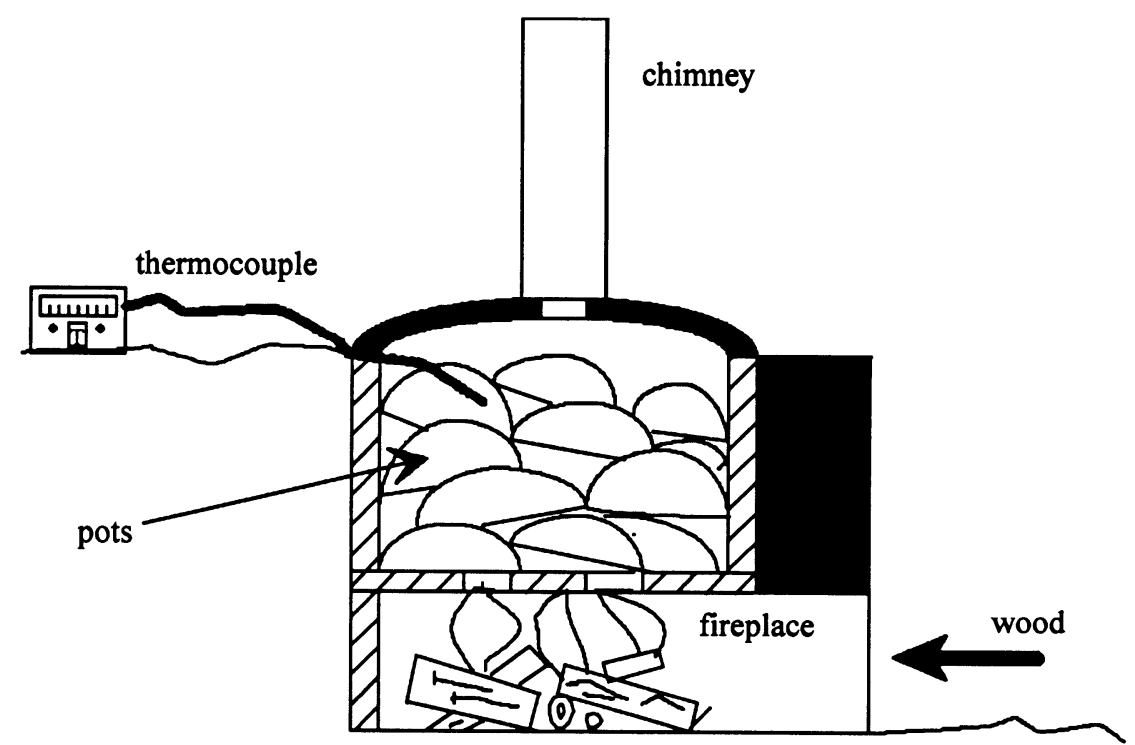

Fig. 1. Diagram of the kiln used for firing experimental potsherds

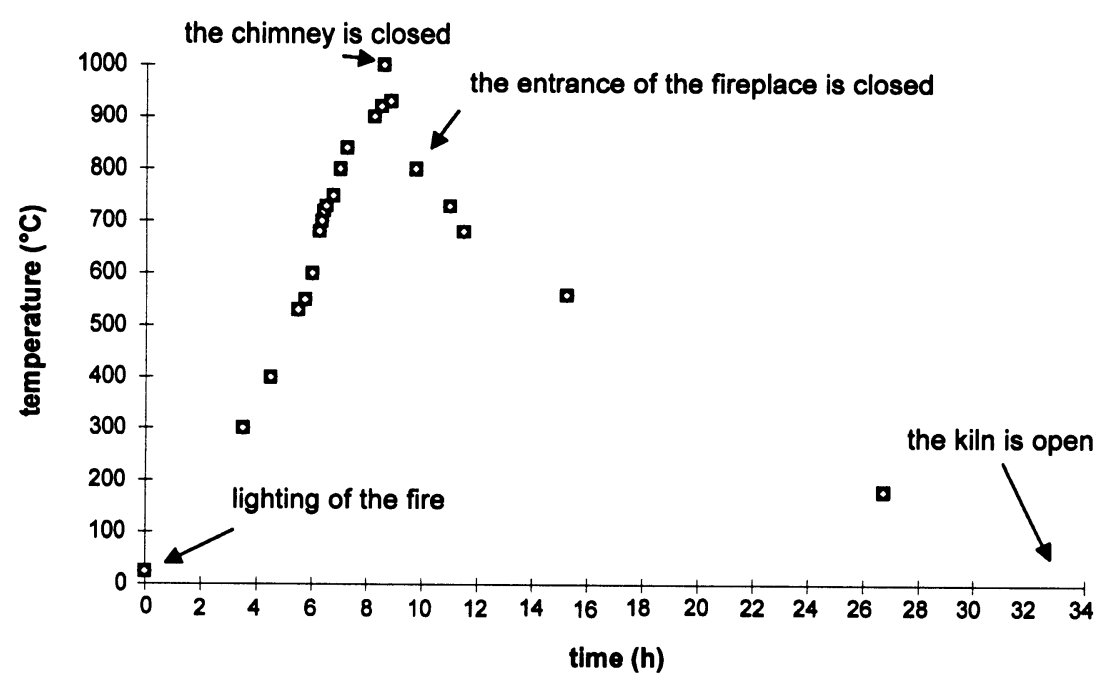

Fig. 2. Plot of kiln temperature and time. The thermocouple is located at the top of the kiln, where the temperature is higher. The temperature can be $200-250^{\circ} \mathrm{C}$ lower at the position of the fired pots. 
In a first trial, two potsherds were selected and combined to form one sample large enough for LSC dating; K2, with a large black core, and K3, with a smaller one (Fig. 3), are typical of the pots produced during the experiment. This sampling is in good agreement with archaeological sampling, where all the sherds do not belong to the same pot. The sample was divided into two fractions of $350 \mathrm{~g}$ each, one powdered and the other remaining in the form of sherds (4-5 cm wide). Carbon was extracted using the device shown in Figure 4 . While the sample is swept with oxygen, a furnace moves along the combustion tube, burning carbon contained in the sample. The furnace is first positioned at one end of the tube and, when the temperature controlled by a thermocouple inserted into
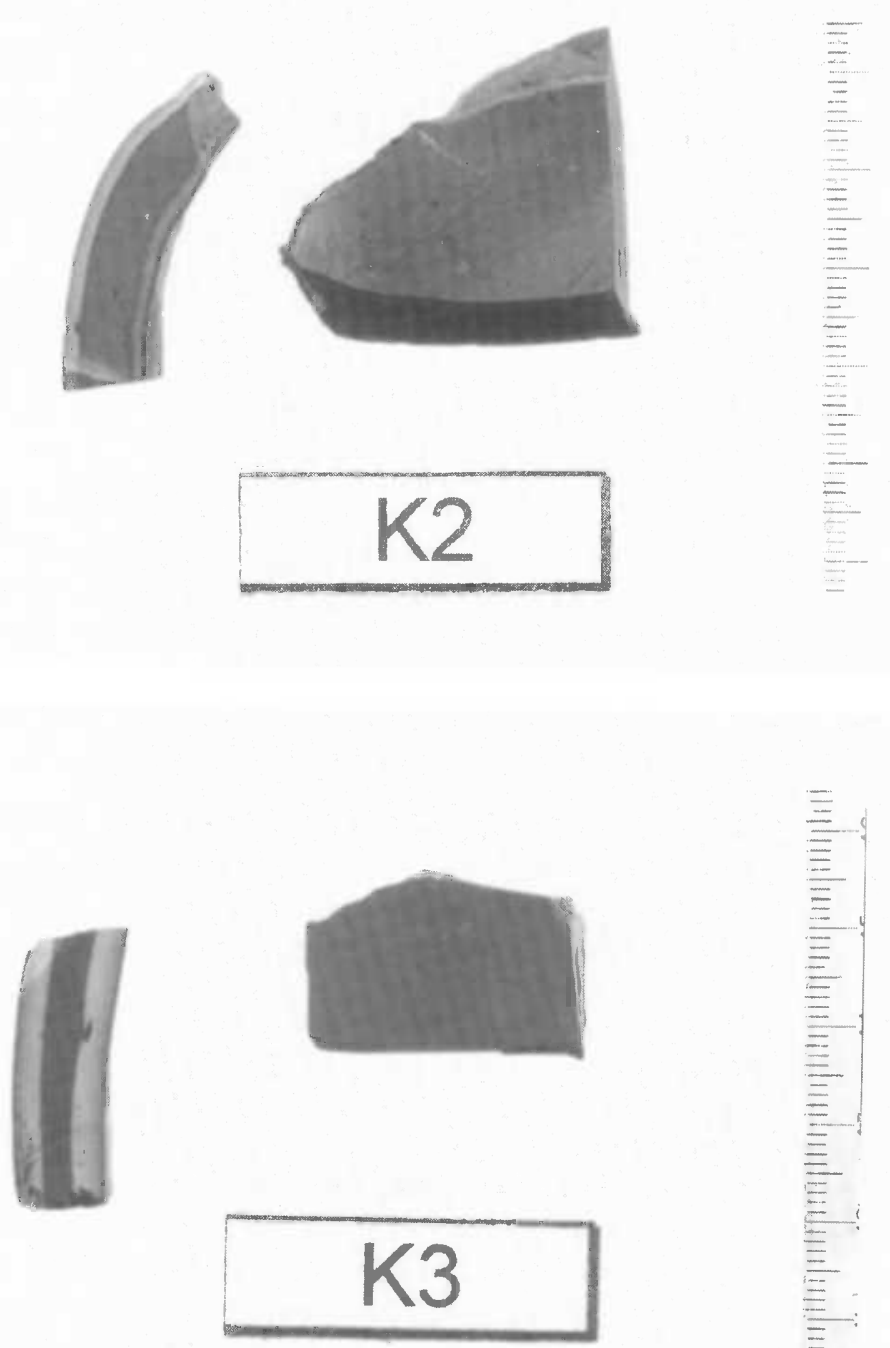

Fig. 3. Broken cross-sections of $\mathrm{K} 2$ and $\mathrm{K} 3$ potsherds, with scale in $\mathrm{cm}$ 
the sample has reached the required value, the furnace is maintained for $c a .30 \mathrm{~min}$ and then it is moved $c a .10 \mathrm{~cm}$. This last operation is repeated all along the sample. Any $\mathrm{CO}$ produced during combustion is oxidized to $\mathrm{CO}_{2}$ by hot $\mathrm{CuO}$. The measurement of $\mathrm{CO}_{2}$ pressure in a known volume gives us the quantity of carbon extracted.

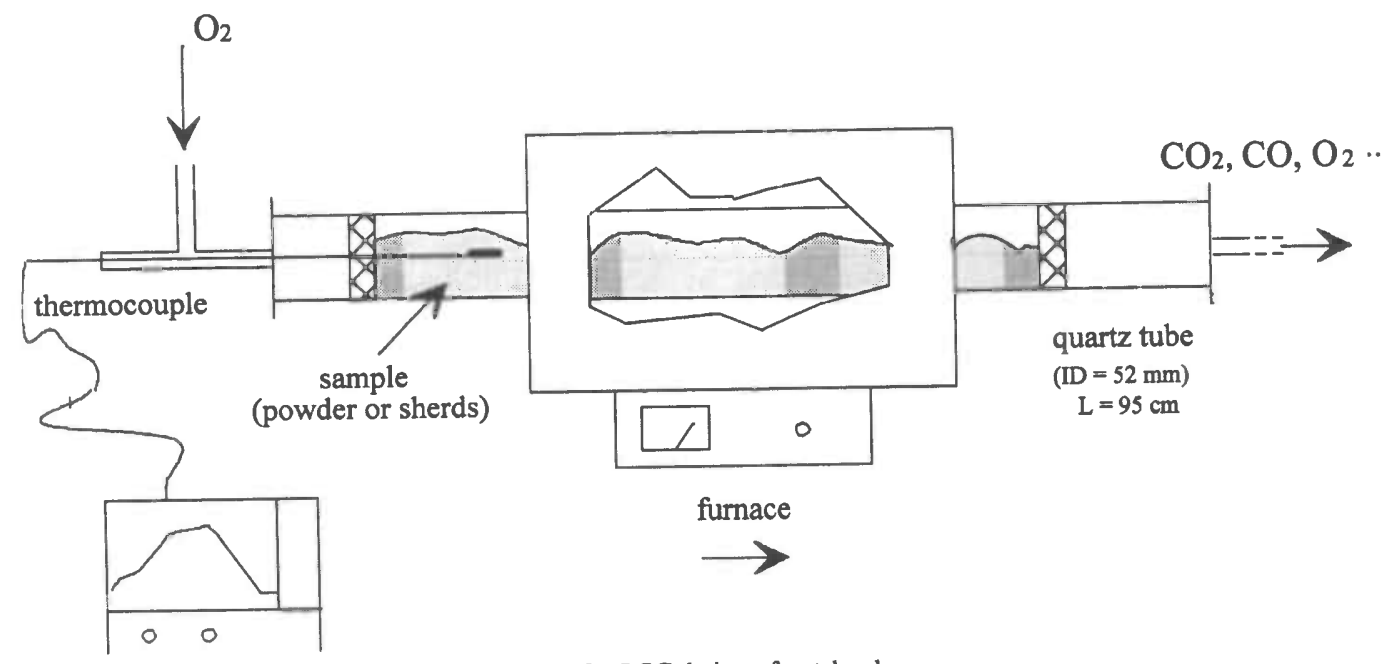

Fig. 4. Combustion device for sample preparation for LSC dating of potsherds

In a second trial, two lamellas were cut in the black outside surface of K3. These lamellas, 3-3.5 mm and 1.5-2 mm thick, with surface areas of $c a .5 \mathrm{~cm}^{2}$ and weights of $c a .2 \mathrm{~g}$, were taken as samples for AMS dating. Carbon extraction differs for AMS, using the device shown in Figure 5. The quartz tube was evacuated to $10^{-3} \mathrm{mbar}$ and filled with $\mathrm{O}_{2}(0.3 \mathrm{bar})$. The valve was closed and the tube put in a furnace at $400^{\circ} \mathrm{C}$ for $10 \mathrm{~min}$. The $\mathrm{CO}_{2}$ formed was collected in a tube where pressure measurement allowed the calculation of carbon content. It was then transferred to a 6-ml ampoule. AMS measurements were performed by the Oxford Radiocarbon Accelerator Unit.

The results of LSC and AMS dating are reported in Table 1. The LSC results, Ly-6244 and Ly-6245, are $<100 \mathrm{pMC}$, which means that carbon from clay has been extracted. Nevertheless, by comparing these two results, we can see that a decrease in combustion temperature diminishes the influence of clay-derived carbon, which supports the conclusions of Evin, Gabasio and Lefevre (1989).

The activities obtained from the lamellas, Lyon-59(OxA) and Lyon-73(OxA), are $>100 \mathrm{pMC}$, which does not exclude the presence of carbon from clay but which proves that carbon from smoke is predominant. The fact that samples were from the surface of the potsherd, where smoke is the major source of carbon, probably explains this. The lower activity of Lyon-59(OxA), which is thicker than Lyon-73(OxA), supports this explanation. During firing, potsherds are exposed first to oxidizing and later to reducing atmospheres. This burns part of the carbon mixed with clay, the most volatile compounds (Johnson et al. 1988); this combustion starts on the external surfaces of the pot and diffuses into the core of the material. The clay structure, the maximum temperature reached and the predominant atmosphere during post-firing (oxidizing or reducing) determine the total combustion of "geological" carbon or of its pyrolysis inside the paste. In our case, the temperature before kiln closing was not high enough to burn all the carbon and a black core appeared. These results suggest that AMS is the more appropriate method for direct dating of potsherds if samples are taken from the pot's surface. 


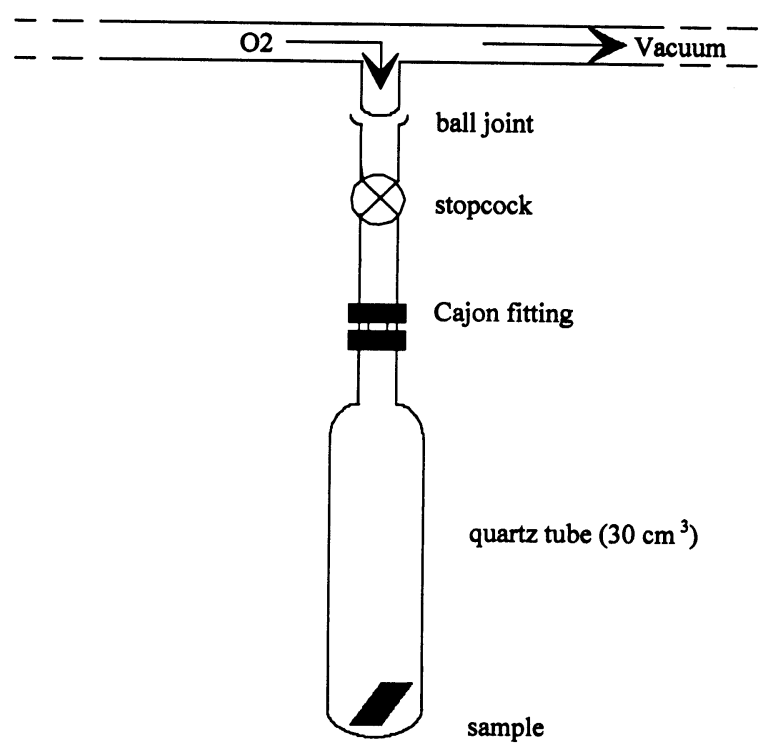

Fig. 5. Combustion device for AMS dating of potsherds

TABLE $1 .{ }^{14} \mathrm{C}$ Activity of Experimental Potsherds Measured by LSC and AMS

\begin{tabular}{llcr}
\hline Lab no. & Material & $\begin{array}{c}\text { Carbon } \\
\text { extracted (\%) }\end{array}$ & $\begin{array}{c}{ }^{14} \mathrm{C} \text { activity } \\
\text { (pMC) }\end{array}$ \\
\hline Ly-6209 & Raw clay & 1.2 & $1.8 \pm 0.3$ \\
& Wood $^{*}$ & -- & $100-200$ \\
Ly-6245 & Powder, burned at $360^{\circ} \mathrm{C}$ & 0.2 & $66.2 \pm 0.9$ \\
Ly-6244 & Powder, burned at $530^{\circ} \mathrm{C}$ & -- & $54.1 \pm 0.5$ \\
Ly-6246 & Sherds, burned at $500^{\circ} \mathrm{C}$ & 0.7 & $53.6 \pm 0.5$ \\
Lyon-59(OxA) & Lamella, 2.2 g, 3-3.5 mm thick & 0.10 & $113.7 \pm 0.7$ \\
Lyon-73(OxA) & Lamella, $1.8 \mathrm{~g}, 1.5-2 \mathrm{~mm}$ thick & 0.15 & $121.6 \pm 0.6$ \\
\hline
\end{tabular}

"Fuel used for firing potsherds is modern wood grown after 1950, therefore subject to the "bomb effect". Consequently, the global activity of the fuel is not precisely known but ranges between 100 and 200 pMC.

\section{Archaeological Sherds}

To investigate the possibility of dating pottery, the use of controlled experimental ceramics is preferable for studying the influences of carbon sources on the date. Nevertheless, this material is a model and, like all models, it does not correspond exactly to reality. Although we can adequately approximate the preparation of a potsherd (forming and firing), it is more difficult to simulate thousands of years of burial or long periods (perhaps several years) of food permeation. In the case of food, the age will reflect the time of use. If these components stay in the sample despite chemical treatments (acid and base), they will be a perfect source of carbon for dating. Humic acids create a problem because this source of carbon is usually younger than the sample. The high porosity of many potsherds-particularly the older ones-favors the penetration of humics, which can resist the 
$\mathrm{NaOH}$ treatments usually recommended for their extraction. The archaeological samples chosen for dating differ in time and place of origin, but all of them have a gray to black surface.

\section{Radiocarbon Analysis}

Despite the unconvincing results obtained by LSC dating of experimental samples, we again used this method for archaeological sherds. The use of very old clay for the experimental pots does not reflect the general case in archaeological pottery. In prehistoric or protohistoric times, clay was collected near the place of manufacture, from deposits near the surface of the soil, and was therefore not of infinite ${ }^{14} \mathrm{C}$ age. For this reason, the combustion method for LSC dating continues to hold promise for investigations with archaeological samples.

All the samples dated by LSC were pulverized and received acid/alkali/acid (AAA) treatment except Ly-6292 from Le Laouret, which was kept in the form of sherds and washed only with $\mathrm{NaOH}$. Humic acid fractions were obtained by acid precipitation of the $\mathrm{NaOH}$ extract. Each AMS sample was taken from one sherd submitted to a basic pretreatment: ultrasonication in $0.5 \mathrm{~N} \mathrm{NaOH}$ for $5 \mathrm{~min}$, followed by $1 \mathrm{~h}$ in an oven at $100^{\circ} \mathrm{C}$ and $12 \mathrm{~h}$ at room temperature. In the case of Locmariaquer, humics were separated. I used the same combustion devices as for the experimental samples.

\section{RESULTS AND DISCUSSION}

Table 2 presents the results of LSC dating of archaeological sherds. See also Figure 6 for a plot of the LSC and AMS dates from all the sites. Five fractions from Le Laouret were dated. Three combustions were made on the powdered fractions. The first and the second one at $360^{\circ} \mathrm{C}(\mathrm{Ly}-6409)$ and

TABLE 2. LSC Dating of Archaeological Sherds

\begin{tabular}{|c|c|c|c|c|c|c|}
\hline Site & Lab no. & Material & $\begin{array}{l}\text { Burning } \\
\text { temperature }\end{array}$ & $\begin{array}{c}\text { Carbon } \\
\text { extracted (\%) }\end{array}$ & $\begin{array}{l}{ }^{14} \mathrm{C} \text { age } \\
\text { (yr BP) }\end{array}$ & Expected age \\
\hline \multirow[t]{5}{*}{ Le Laouret } & Ly-6409 & Powder & $360^{\circ} \mathrm{C}$ & 0.3 & $2805 \pm 55$ & \\
\hline & Ly-6410 & & $450^{\circ} \mathrm{C}$ & 0.3 & $2970 \pm 70$ & $2900-2750$ BP \\
\hline & Ly-6411 & & $600^{\circ} \mathrm{C}$ & 0.1 & $3730 \pm 110$ & \\
\hline & Ly-6307 & Humics & $>850^{\circ} \mathrm{C}$ & 8.0 & $1760 \pm 100$ & Bronze Age \\
\hline & Ly-6292 & Sherds & $300^{\circ} \mathrm{C}$ & 0.3 & $1435 \pm 70$ & \\
\hline \multirow{4}{*}{$\begin{array}{l}\text { La Fosse } \\
\text { Toumise, } \\
\text { maison } 165\end{array}$} & Ly-6773 & Powder & $400^{\circ} \mathrm{C}$ & 0.9 & $5775 \pm 75$ & Ly-6479: $5835 \pm 85$ BP \\
\hline & Ly-6595 & & $430^{\circ} \mathrm{C}$ & 0.9 & $6260 \pm 65$ & Ly-6477: $5275 \pm 75$ BP \\
\hline & Ly-6596 & & $650^{\circ} \mathrm{C}$ & 0.3 & $7255 \pm 165$ & (bones) \\
\hline & Ly-6632 & Humics & $>850^{\circ} \mathrm{C}$ & 33.0 & $5925 \pm 85$ & Neolithic \\
\hline \multirow[t]{4}{*}{ Lingolsheim } & Ly-6716 & Powder & $360^{\circ} \mathrm{C}$ & 0.8 & $2880 \pm 55$ & Ly-6430: $2535 \pm 80 \mathrm{BP}$ \\
\hline & Ly-6591 & & $450^{\circ} \mathrm{C}$ & 0.7 & $3115 \pm 50$ & (charcoal) \\
\hline & Ly-6592 & & $630^{\circ} \mathrm{C}$ & 0.3 & $3740 \pm 115$ & Iron Age, Hallstatt c \\
\hline & Ly-6933 & Humics & $>850^{\circ} \mathrm{C}$ & 10.0 & $1390 \pm 100$ & \\
\hline \multirow[t]{3}{*}{ Les Barlières } & Ly-6771 & Powder & $400^{\circ} \mathrm{C}$ & 0.4 & $3530 \pm 55$ & Ly-3776: $2630 \pm 110$ BP \\
\hline & Ly-6772 & & $440^{\circ} \mathrm{C}$ & 0.2 & $3322 \pm 205$ & (wood) \\
\hline & Ly-6307 & Humics & $>850^{\circ} \mathrm{C}$ & 9.0 & $1760 \pm 100$ & Late Bronze Age \\
\hline \multirow{3}{*}{$\begin{array}{l}\text { Saint-Victor- } \\
\text { des-Oules }\end{array}$} & Ly-6593 & Powder & $400^{\circ} \mathrm{C}$ & 0.1 & $2025 \pm 85$ & $850-950$ вР \\
\hline & Ly-6594 & & $650^{\circ} \mathrm{C}$ & $<0.1$ & $1515 \pm 120$ & \\
\hline & Lyon-72(OxA) & Humics & $850^{\circ} \mathrm{C}$ & 6.0 & $1445 \pm 45$ & 12th century \\
\hline
\end{tabular}




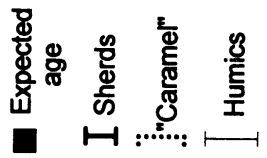

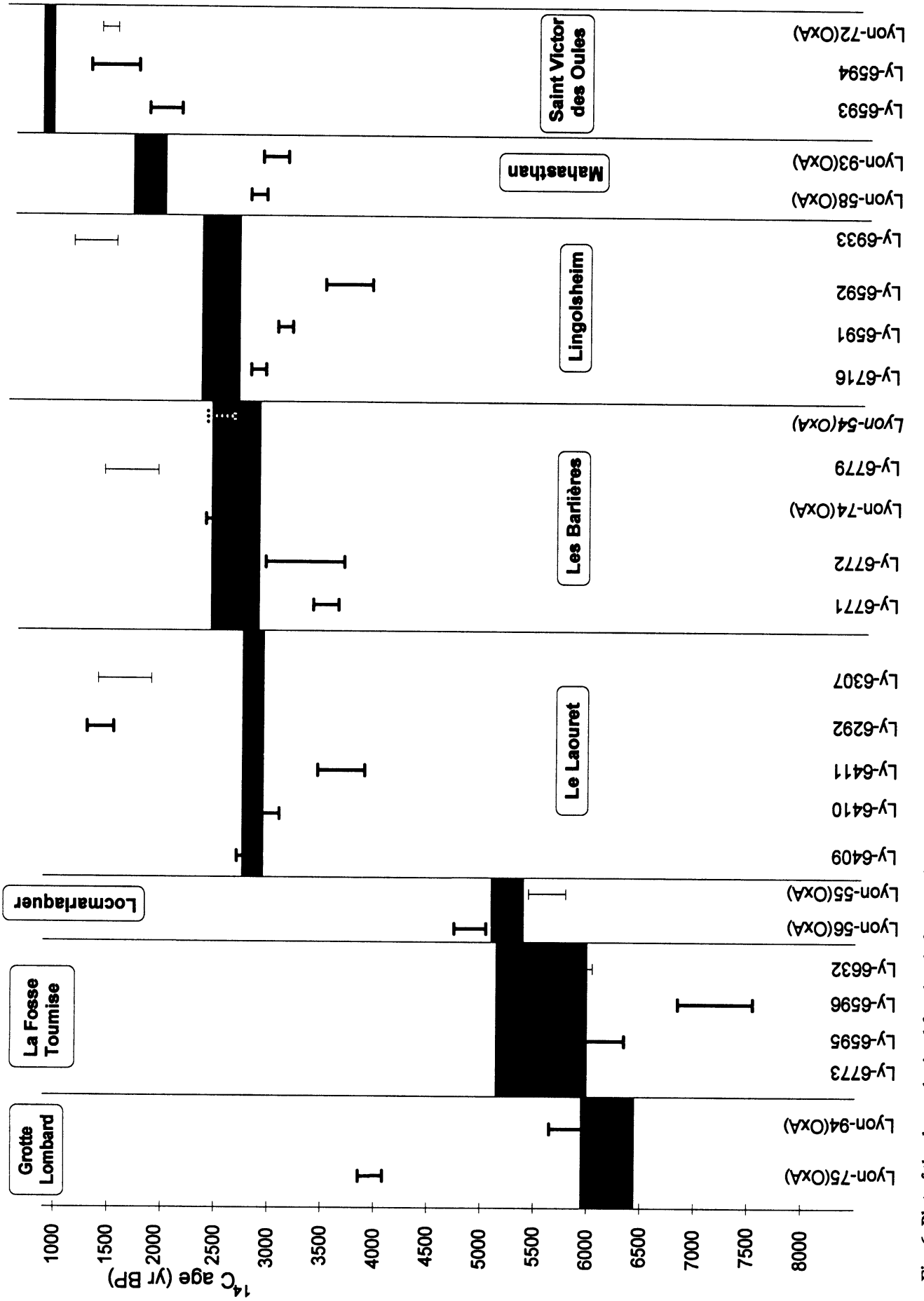


$450^{\circ} \mathrm{C}$ (Ly-6410) were not significantly different; the dates obtained agree well with the archaeologically expected date. The high-temperature burning $\left(600^{\circ} \mathrm{C}\right)$ gives an older date, showing that geological carbon from clay was extracted. As expected, the humics are too young. The date obtained from whole sherds is not far from that of the humics, meaning that the $\mathrm{NaOH}$ pretreatment was ineffectual; the carbon released at low temperature $\left(300^{\circ} \mathrm{C}\right)$ comes from humics in the burial soil. The dates obtained for powdered fractions from La Fosse Toumise, Maison 165 and Lingolsheim support the results of Le Laouret: low temperatures $\left(400^{\circ} \mathrm{C}\right.$ for La Fosse Toumise and $360^{\circ} \mathrm{C}$ for Lingolsheim) give the best results. For La Fosse Toumise, the humics date is perfectly consistent with the dated bones from the same level. For Les Barlières, the carbon was entirely oxidized at $440^{\circ} \mathrm{C}$ (no carbon was found at $\left.650^{\circ} \mathrm{C}\right)$; the dates obtained at $400^{\circ} \mathrm{C}(\mathrm{Ly}-6771)$ and at $440^{\circ} \mathrm{C}(\mathrm{Ly}-6772)$ are both in the same range and are too old compared to the dated wood from the site. For Saint-Victor-desOules, all the results are too old, and they contradict the expectations of selective heat treatment. The light gray color of this medieval pottery shows that reducing conditions were present during firing but produced little soot. Thus, the carbon concentration is too low for good results. This is typical of these gray sherds from Roman or Medieval periods. Humics (Lyon-72(OxA)) were prepared from the powder fraction but were dated by AMS because of their small quantity. The old date obtained for humics seems to show that the fraction I call "humics" does not fully represent the burial context but also includes carbon from manufacturing clay finely dispersed by the alkali treatment.

Table 3 presents the results of AMS dating of archaeological sherds. For Lombard, the date obtained for sherd Lyon-75(OxA) is much too young compared with charcoal from the same level. No humics could be separated out after $\mathrm{NaOH}$ treatment. I could not establish whether pretreatment was at fault, which would mean the humics remaining in the sherd contributed to this young date, or if there were no humics, which would mean only an unknown external contamination (at any stage of the

TABLE 3. AMS Dating of Archaeological Sherds

\begin{tabular}{|c|c|c|c|c|c|c|}
\hline Site & Lab no & Material & $\begin{array}{l}\text { Burning } \\
\text { conditions }\end{array}$ & $\begin{array}{c}\text { Carbon } \\
\text { extracted } \\
(\%)\end{array}$ & $\begin{array}{r}{ }^{14} \mathrm{C} \text { age } \\
\text { (yr BP) } \\
\end{array}$ & Expected age \\
\hline \multirow[t]{2}{*}{ Lombard } & Lyon-75(OxA) & $\begin{array}{l}\text { Sherd, black internal } \\
\text { surface and red external } \\
\text { surface }\end{array}$ & $30 \mathrm{~min}, 400^{\circ} \mathrm{C}$ & 0.2 & $3955 \pm 50$ & $\begin{array}{l}\text { Ly-3331: } 6190 \pm 120 \mathrm{BP} \\
\text { Ly-3332: } 6110 \pm 120 \mathrm{BP} \\
\text { (charcoal) }\end{array}$ \\
\hline & Lyon-94(OxA) & Lamella, 1-2 mm thick & $30 \mathrm{~min}, 450^{\circ} \mathrm{C}$ & 0.7 & $5875 \pm 65$ & Neolithic \\
\hline \multirow[t]{2}{*}{$\begin{array}{l}\text { Locmariaquer } \\
\text { "Er Grah" }\end{array}$} & Lyon-56(OxA) & $\begin{array}{l}\text { Sherd } \\
\text { partially disintegrated } \\
\text { in alkali solution }\end{array}$ & $1 \mathrm{~h}, 400^{\circ} \mathrm{C}$ & 0.8 & $4885 \pm 65$ & $\begin{array}{l}\text { Gif-7691: } 5250 \pm 70 \mathrm{BP} \\
\text { (charcoal) }\end{array}$ \\
\hline & Lyon-55(OxA) & Humics & $30 \mathrm{~min},>850^{\circ} \mathrm{C}$ & 5.0 & $5650 \pm 90$ & \\
\hline \multirow[t]{2}{*}{ Les Barlières } & Lyon-74(OxA) & $\begin{array}{l}\text { Lamella taken in black } \\
\text { external surface of a } \\
\text { sherd, } 1-2 \mathrm{~mm} \text { thick }\end{array}$ & $30 \mathrm{~min}, 450^{\circ} \mathrm{C}$ & 0.3 & $2560 \pm 50$ & $\begin{array}{l}\text { Ly-3776: } 2630 \pm 110 \mathrm{BP} \\
\text { (wood) } \\
\text { Late Bronze Age }\end{array}$ \\
\hline & Lyon-54(OxA) & Food remains & $30 \mathrm{~min},>850^{\circ} \mathrm{C}$ & 58.0 & $2560 \pm 50$ & \\
\hline \multirow[t]{2}{*}{ Mahasthan } & Lyon-58(OxA) & $\begin{array}{l}\text { Totally black sherd. } \\
\text { After burning, becomes } \\
\text { orange on surface and } \\
\text { brown to black inside }\end{array}$ & $20 \mathrm{~min}, 500^{\circ} \mathrm{C}$ & 0.5 & $2890 \pm 50$ & $2000-1700 \mathrm{BP}$ \\
\hline & Lyon-93(OxA) & Lamella $0.5 \mathrm{~mm}$ thick & $30 \mathrm{~min}, 400^{\circ} \mathrm{C}$ & 0.6 & $3050 \pm 55$ & \\
\hline
\end{tabular}


analysis process) could explain this result. However, burning of a thin lamella black outside surface of the same sherd gives a date concordant with expectations. The date of the sherd Locmariaquer "Er Grah" is consistent with the archaeological data, but the humics are too old. As for Saint Victor des Oules, the real content of this "humics" fraction remains questionable. Les Barlières, Lyon$74(\mathrm{OxA})$, is a thin lamella cut from the black external surface of a sherd; as with Lyon-73(OxA)(K3 sherd), to which it can be compared for treatment, Lyon-74(OxA) gives the expected date. I also scraped from the internal surface of a sherd a sort of caramel identified with food remains by its high lipid content (Delqué Kolix 1995; Formenti et al. 1995). After an AAA treatment, food remains give a date perfectly consistent with the sherd date. The sherds from Mahasthan, Bangladesh, have a brown to black body and black gloss surfaces. They seem comparable to the Indian Northern Black Polished Wares described by Gillies and Urch (1983). Compared to the other samples, their carbon content $\left(0.5 \%\right.$ carbon extracted after $20 \mathrm{~min}$ at $\left.500^{\circ} \mathrm{C}\right)$ may not be the only explanation for the deep black color. The orange coloration of the sherd observed after burning indicates the presence of iron oxides; the conversion of these iron oxides to magnetite under reducing conditions is, as in other numerous potsherds worldwide (Hyman and Rowe 1990), a blackening agent. A whole sherd (Lyon$58(\mathrm{OxA})$ ) and a lamella taken from the surface of a sherd (Lyon-93(OxA)) give similar dates that appear too old based on the few results available for this site. Two hypotheses can be proposed: 1) in spite of the firing, carbon from clay has remained at the surface of the potsherds; 2) soot deposited on and inside the potsherds under reducing conditions came from old carbon sources such as peat.

\section{CONCLUSION}

This study shows that, for brown to black potsherds, combustion at low temperature $\left(\leq 400^{\circ} \mathrm{C}\right)$ decreases the effect of contamination by old carbon from clay. In addition, I observed that, with experimental potsherds, results were better when samples were put in the form of thin lamellas taken from the surface of sherds. When employed for archaeological sherds, this type of sampling is not so conclusive because of the external contaminants introduced, for example, by burial soil. The alkali pretreatment of the lamellas discussed in this study should be completed with acid cleaning on the powdered lamellas. This could improve the efficiency of such a "thin lamella" method and allow extraction of contemporaneous sources of carbon such as smoke and food remains. The "good" carbon could also be retrieved from the surface of a black potsherd by laser combustion. This method, proposed by Watchman and Lessard (1993) for dating rock art, may be used to burn a very thin part of the surface without extracting carbon from clay.

\section{ACKNOWLEDGMENTS}

I thank G. B. Arnal, who directed the firing of experimental potsherds, and also C. Pachiaudi, who measured isotopic fractionations.

\section{REFERENCES}

De Atley, S. P. 1980 Radiocarbon dating of ceramic materials: Progress and prospects. In Stuiver, M. and Kra, R. S., eds., Proceedings of the 10 th International ${ }^{14} \mathrm{C}$ Conference. Radiocarbon 22(3): 987-993.

Delqué Kolix, E. (ms.) Méthodes d'extraction du carbone des poteries pour le leur datation par le radiocarbone. PhD. dissertation, Lyon: $139 \mathrm{p}$.

(ms.) 1995 Méthodes d'estraction du carbone des poterics pour leur datatión por le radiocarbone. Ph.D. dissertation, Lyon: $139 \mathrm{p}$.
Evin, J., Gabasio, M. and Lefevre, J. C. 1989 Preparation techniques for radiocarbon dating of potsherds. In Long, A., Kra, R. S. and Srdox, B., eds., Proceedings of the 13th International ${ }^{14} \mathrm{C}$ Conference. Radiocarbon 31(3): 276-283.

Formenti, F., Lestriez, B., Ecuvillon, S., Evans, J. (ms.) 1995. Analyses de résidus alimentaires appelés "caramels". Critique et interprétation archéologique des résultats analytiques. Paper presented at Colloque d'Archéométrie: l'Archéométrie dans les pays eu- 
ropéens de langue latine, Périgueux, France, 26-29 April 1995.

Gabasio, M., Evin, J., Arnal, G. B. and Andrieux, P. 1986 Origins of carbon in potsherds. In Stuiver, M. and Kra, R. S., eds., Proceedings of the 12 th International ${ }^{14} \mathrm{C}$ Conference. Radiocarbon 28(2A): 711-718.

Gillies, K. J. S. and Urch, D. S. 1983 Spectroscopic studies of iron and carbon in black surfaced wares. Archaeometry 25(1): 29-44.

Hedges, R. E. M., Chen, T. and Housley, R. A. 1992 Results and methods in the radiocarbon dating of pottery. In Long, A. and Kra, R. S., eds., Proceedings of the 14th International ${ }^{14} \mathrm{C}$ Conference. Radiocarbon 34 (3): 906-915.

Hyman, M., Rowe, M. W. 1990 Origin of color of American Indian black and red ceramics. The Texas Journal of Science 42(1): 55-67.

Johnson, J. S., Clark, J., Miller-Antonio, S., Robins, D.,
Schiffer, M. B. and Skibo, J. M. 1988 Effects of firing temperature on the fate of naturally occurring organic matter in clays. Journal of Archaeological Science 15: 403-414.

Johnson, J. S., Stipp, J. J., Tamers, M. A., Bonani, G., Suter, M. and Wolfli, W. 1986 Archaeologic sherd dating: Comparison of thermoluminescence dates with radiocarbon dates by beta counting and accelerator techniques. In Stuiver, M. and Kra, R. S., eds., Proceedings of the 12 th International ${ }^{14} \mathrm{C}$ Conference. $R a$ diocarbon 28(2A): 719-725.

Watchman, A. L. and Lessard, R. 1993 Focused laser extraction of carbonaceous substances for AMS radiocarbon dating (FLECS-AMS). In Steinbring, J. and Watchman, A., eds., Proceedings of Symposium "The Dating of Rock Art". Occasional AURA publication 8, Australian Rock Art Research Association, Melbourne: 74-77. 